\title{
Synthesis and Testing of Catalysts for Decrease of Toxic Emissions of Vehicles
}

\author{
Y.A. AUBAKIROV ${ }^{1}$, L.R.SASSYKOVA ${ }^{1 *}$, A.M. NALIBAYEVA², K. DOSSUMOV ${ }^{3,4}$, \\ ZH.KH.TASHMUKHAMBETOVA ${ }^{1}$, A.S. ZHUMAKANOVA ${ }^{2}$, A.K. ZHUSSUPOVA ${ }^{1}$ \\ and N.K. ZHAKIROVA ${ }^{1}$
}

${ }^{1}$ Al-Farabi Kazakh National University, 71, al-Farabi ave., 050040, Almaty, Kazakhstan.

${ }^{2}$ D.V.Sokolsky Institute of Fuel, Catalysis \& Electrochemistry, 142, D.Kunaev str., 050010, Almaty, Kazakhstan.

${ }^{3}$ Scientific Research Institute of New Chemical Technologies and Materials, 95a, Karasaibatyr str., 050012, Almaty, Kazakhstan.

${ }^{4}$ The Combustion Problems Institute, 172, Bogenbaibatyr str., 050012, Almaty, Kazakhstan. ${ }^{\star}$ Corresponding author E-mail: larissa.rav@mail.ru

http://dx.doi.org/10.13005/ojc/330655

(Received: September 13, 2017; Accepted: October 20, 2017)

\section{ABSTRACT}

\begin{abstract}
Catalysts on the metal block carriers for decrease exhaust gases of motor transport were synthesized and tested. Stability of the carrier and the active phase of the catalysts to poisons $\mathrm{SO}_{2}$ and oxygen in the processes of cleaning of exhaust gases was studied. In the presence of $3 \%$ oxygen, the catalyst activity was considerably increased, especially for $\mathrm{Co}+\mathrm{Mn}$ and $\mathrm{Ni}+\mathrm{Mn}$, but increase in content of oxygen to $10 \%$ reduced effectiveness of catalysts. Nickel-manganese catalyst promoted with $0.1 \mathrm{wt}$ \% Pt was the most stable against oxygen influence. The activity of catalysts based on $\mathrm{Pt}, \mathrm{Pt}+\mathrm{Pd}, \mathrm{Pd}$ in presence of $\mathrm{SO}_{2}$ decreased at low test temperatures, but after calcination at $500^{\circ} \mathrm{C}$ with air blowing for $2 \mathrm{~h}$ activity of Pt catalyst was almost returned and reached $80 \%$. After the tests of the catalysts at the stand on the basis of the diesel generator (5GF-LDE with power of $5 \mathrm{kVA}$ ) degree of conversion of $\mathrm{CO}$ was $99.6 \%$, hydrocarbons $-80.7 \%$, nitrogen oxides $-60-61.9 \%$.
\end{abstract}

Keywords: Ecology, Exhaust gases, Catalysts, Block carriers, Catalyst poisons

\section{INTRODUCTION}

In general, emissions of pollutants and greenhouse gases into the atmosphere from industrial activities and transport are formed from the emissions of stationary and mobile sources. The source of emission of harmful substances of a motor vehicle is the internal combustion engine installed on it. In the exhaust gases of the engine contain more than 200 toxic chemical compounds. Except direct negative impact on health of the person, emissions of the motor transport have greenhouse and ozone-depleting effect on the atmosphere of the earth ${ }^{1-4}$. It relates to the content 
in the fulfilled gases of the engine of the following substances: carbon dioxide $\mathrm{CO}_{2}$, the main component in the exhaust gases of the engine, creating a greenhouse effect in the atmosphere (greenhouse gas); methane $\mathrm{CH}_{4}$, ammonia $\mathrm{NH}_{3}$ and nitrous oxide $\mathrm{N}_{2} \mathrm{O}$ - greenhouse and ozonedepleting substances contained in the exhaust gases of the engine ${ }^{5-9}$. The qualitative and quantitative indicators of the release of harmful pollutants with exhaust gases of vehicles during their transport work are ambiguous and depend on many factors: on the type of the used fuel, from the design, conditions and operating conditions of the engine, on the amount of the done work, on the type and characteristics of the car's movement ${ }^{10-13}$. Therefore real quantitative assessment of emissions of pollutants and greenhouse gases in the atmosphere from the motor transport is a difficult task. Growth of environmental pollution from the motor transport and of number of vehicle fleet were the reason of toughening of requirements to qualitative ecological characteristics of products of oil-processing industry ${ }^{14-16}$. Today reduction of harmful emissions of motor transport and industry to necessary standards is possible only with use of catalytic methods, which are the most effective means of cleaning. Monolithic ceramic and metallic blocks are one of the most suitable carriers of the catalysts from the list of materials applied for the solution of ecological issues. They are capable of withstanding loads produced during operation under actual operating conditions, as well as meet the requirements of the catalytic converters. Total removal of toxic gases and poisons in the presence of an effective catalyst is possible at the optimum ratio of oxidizing and reducing agents ${ }^{17-20}$.

The objective of this work was preparation of catalysts on the block metal carriers with the different active phase and different composition of washcoats and testing their activity and stability to different poisons in the processes of neutralization of toxic emissions of the motor transport.

\section{MATERIALS AND METHODS}

In the work were used catalysts of purification of exhaust gases of motor transport and harmful emissions of the industry based on monolithic metal blocks. Catalysts have a cylindrical shape and are convenient in placing at the source of toxic emissions ${ }^{21}$. As primary inert carrier the tape from a steel foil (goffered and folded into the block) the $\mathrm{H} 23 \mathrm{Yu} 5, \mathrm{H} 15 \mathrm{Yu} 5$ brands containing about 5\% of aluminum is applied. The foil is subjected to a heat treatment at a temperature $850-920^{\circ} \mathrm{C}$ in air or oxygen during 12-15 hours. Formed on the surface the alumina is necessary for increase in adhesion of the intermediate covering to a surface of a steel foil. Intermediate (secondary) coating, a washcoat, is deposited by the suspension method on this treated primary carrier at room temperature. As the washcoats are used alumina with the addition of zeolite and alumina modified by additives of compounds on the base of $\mathrm{Ce}, \mathrm{Ti}, \mathrm{Zr}$, La and Fe. Suspension for the catalysts preparation represents water alcohol solution (water-ethanol) with a ratio water-alcohol 1:1, in which it was dispersed 22.032.0 wt. \% of $\mathrm{Al}(\mathrm{OH})_{3}$ and it was dissolved 2.0-4.0 wt. $\%$ of $\mathrm{Al}\left(\mathrm{NO}_{3}\right)_{3}$ and 2.0-5.0 wt.\% of $\mathrm{Ce}\left(\mathrm{NO}_{3}\right)_{2}$. Using this suspension allows for once (single immersion) applied to the support block from 7.0 to $14.0 \mathrm{wt} \%$ of alumina as an intermediate coating which greatly reduces the duration of catalyst preparation. The addition of aluminum nitrate into the system is carried out for plasticizing the suspension to the required level, ensuring higher intermediate coating adhesion to the metal surface of the carrier. Directly into the suspension is also added $\mathrm{Ce}\left(\mathrm{NO}_{3}\right)_{2}$, forming during the heat treatment of it cerium oxide is a thermostabilizing additive of intermediate coating from alumina, particularly in the case of using the catalyst in a possible thermal shocks. To additionally increase the mass of washcoat, after drying the metal block was immersed into a slurry again and then the stages of drying and calcining are carried out. After preparation the prepared catalyst has the characteristics: $\mathrm{Al}_{2} \mathrm{O}_{3}$ content in the catalyst - 7.014.0 wt. \%; $\mathrm{Al}_{2} \mathrm{O}_{3}$ specific surface area - 120-130 $\mathrm{m}^{2} / \mathrm{g}$; content of $\mathrm{CeO}_{2}$ in $\mathrm{Al}_{2} \mathrm{O}_{3}$ - 8.0-15.0 wt.\%. After supporting the intermediate coating the block is impregnated with aqueous solutions of the corresponding active metals. For preparation of solutions of the active components of the catalysts were applied oxides of $\mathrm{Mn}, \mathrm{Ni}, \mathrm{Co}, \mathrm{Fe}$, prepared from acetates and formates. Also the compounds on the base of Pt-group metals were used. The previously weighed blocks were immersed in a solution of salts (acetate or formate) of metal were shaken slightly from the excess solution between the blocks of channels, then were dried at $600^{\circ} \mathrm{C}$ for $2 \mathrm{~h}$. In a furnace, after that procedure they were 
calcined in an electric furnace at $600^{\circ} \mathrm{C}$ for $2 \mathrm{~h}$. In this case metal salts are decomposed to form metal oxides on the surface of the carrier the block. In the work for increasing the activity of platinum catalysts in the reactions of oxidation of $\mathrm{CO}$, hydrocarbons and nitrogen oxides decomposition as a rule platinum metals were transferred to a colloidal state by impregnation of catalysts by the previously prepared solutions of polymers with inclusion of solutions of the deposited metals with the subsequent thermal decomposition. In this work the platinum nano-size particles were prepared by reduction with hydrogen in an aqueous solution containing chloroplatinic acid and citric acid. As the stabilizer of colloid platinum particles is used isopropyl alcohol. Also in the synthesis of catalysts based on platinum and palladium as active components of catalysts acetates of $\mathrm{Pt}$ and $\mathrm{Pd}$ and their $\pi$-complexes are used. Solutions of acetate of palladium were prepared by dissolution of $\mathrm{Pd}$ in the acetic acid containing $3 \%$ of $\mathrm{HNO}_{3}$. Nitric acid was removed in the course of evaporation before complete cessation of release of nitrogen oxides. $\pi$-complexes of $\mathrm{Pd}$ and $\mathrm{Pt}$ were prepared by reacting of allyl alcohol with the salts of these metals with subsequent drying of the catalysts at $150^{\circ} \mathrm{C}$ and calcination at $\mathrm{T}=500^{\circ} \mathrm{C}$ for 2 hours. For increase of thermal stability catalysts were modified with additives of the second metal and oxides of refractory metals. In this work for the synthesis of active and sulfur-stable catalysts into the composition of carrier the modified natural clinoptillolit of Shankanay (Kazakhstan) field (5\%) and high silica zeolite ZSM-5 (module 30) were added. As a part of the initial clinoptillolit-containing sample (\%wt.) in particular such components were $\%: \mathrm{SiO}_{2}-65.0 ; \mathrm{Al}_{2} \mathrm{O}_{3}-6.0 ; \mathrm{Fe}_{2} \mathrm{O}_{3}-4.0 ; \mathrm{Na}_{2} \mathrm{O}_{3}-0.3 ; \mathrm{K}_{2} \mathrm{O}_{3}-$ 0.5. At preparing of the modified clinoptillolit for decationation and dealumination the initial sample was treated with solutions of sulfuric acid 0.25-5.0 $\mathrm{n}$ for $3 \mathrm{~h}$ at a temperature of $100^{\circ} \mathrm{C}$ and a ratio of the solid and liquid phases 1:10, then was washed with distilled water and was added $0.2 \mathrm{n}$ ammonium chloride solution. The samples were then calcined at a temperature of $550^{\circ} \mathrm{C}$ for $4 \mathrm{~h}$ in an air atmosphere. Into catalyst composition as additives were added platinum, cobalt, nickel, manganese, iron, and their mixtures. The BET surface of the catalyst was $4.8-15.0 \mathrm{~m}^{2} / \mathrm{g}$.
Testing of catalysts was carried out by previously developed methodology, for laboratory tests the flowing catalytic installation with the tubular reactor of integrated type was applied ${ }^{21-23}$. The gas mixture was prepared by feeding of hydrocarbons from container and the compressed air from the line into the mixer. The content of hydrocarbon in the mixture was about $0.5 \%$. The oxygen concentration was varied from 2.0 to 10.0 vol.\%. The gas mixture was analyzed by GLC and gas analyzer "OPTOGAS-500.3" before and after the reaction. Crystal 2000M and Chrom 3700 chromatographs with the flame ionization detector are used. Total duration of analysis is 20-30 minutes. The activity of the catalysts was determined at temperatures of 150$500^{\circ} \mathrm{C}$. Characteristic of activity of the catalyst was the degree of conversion $(\alpha)$ of initial substance (hydrocarbon, carbon monoxide, nitric oxide).

The samples of the catalysts were analyzed by EM on EM-125 K microscope by method of one-stage replicas. The $\mathrm{X}$-ray phase analysis method of the synthesized catalysts was carried out on the X-ray DRON-4-0.7 diffractometer with the copper anode. Samples for research were prepared by mechanical destruction of the catalyst put on a block metal framework. The fallen part of the catalyst was crushed in an agate mortar up to $100 \mu$ and was used for research by method XRD.

In this work the stand on the basis of the diesel generator of brand 5GF-LDE with power of $5 \mathrm{kVA}$ for the test of full-size samples of converters ${ }^{23}$ was mounted. For these tests the block catalyst has diameter $30 \mathrm{~mm}$, height $90 \mathrm{~mm}$ and volume $63.4 \mathrm{~mm}^{3}$. As a load device the rheostats are served. Samples before and after the catalyst were selected in all operating modes of the diesel engine (from idle up to $4 \mathrm{kVA}$ ) directly from exhaust pipe by a gas analyzer "OPTOGAS-500.3".

\section{RESULTS AND DISCUSSION}

The researches of stability of the synthesized catalysts to catalytic poisons were carried out. The poisoning action of $\mathrm{SO}_{2}$ in the process of cleaning of combustion gases was studied. XPS research of freshly prepared and waste (after the long-run tests of $50 \mathrm{~h}$ ) catalysts showed that the reason of decrease of the activity of the Ptcontaining catalysts in the course of purification of 
products of combustion of fuel is associated to accumulation of sulfur compounds ${ }^{24}$. As for activity and stability to $\mathrm{SO}_{2}\left(0.1 \%\right.$ in air for $10 \mathrm{~h}$ at $\left.350^{\circ} \mathrm{C}\right)$ of catalysts based on $\mathrm{Pt}, \mathrm{Pt}+\mathrm{Pd}, \mathrm{Pd}$ it was revealed that the catalyst activity is reduced at low test temperatures, but after calcination at $500^{\circ} \mathrm{C}$ with air blowing for $2 \mathrm{~h}$ activity of $\mathrm{Pt}$ catalyst is almost recovered and activity of the $\mathrm{Pd}$-catalyst was reached $80 \%$ (Figure.1, 2).

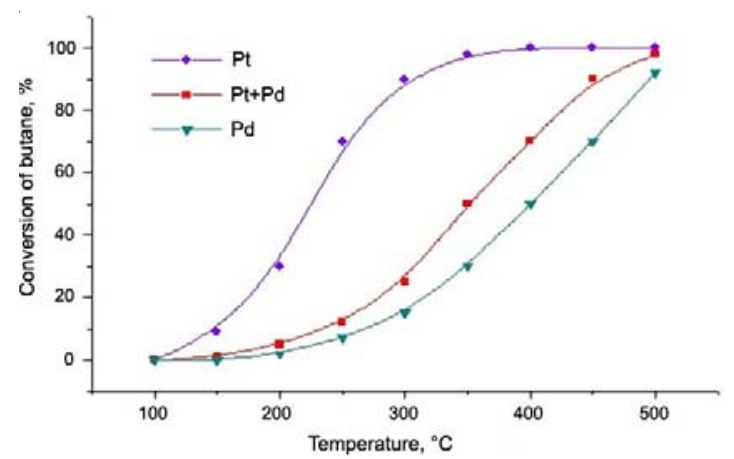

Fig.1. Oxidation of propane - butane mixture in air at $36,000 \mathrm{~h}^{-1}$ on $\mathrm{Pt}, \mathrm{Pt}+\mathrm{Pd}$, Pd-catalysts

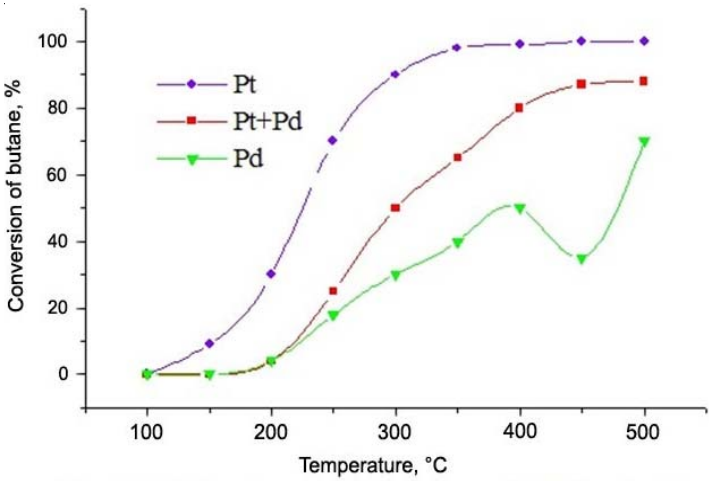

Fig.2. Oxidation of propane - butane mixture in air after poisoning of catalysts by $0.1 \%$ of $\mathrm{SO}_{2}$ within 10 hour.

The activity of the freshly prepared catalyst and spent (exhausted) catalyst sample in the presence of $\mathrm{SO}_{2}$ (after long-term tests for $50 \mathrm{~h}$ ) in the reaction of selective catalytic reduction (SCR) of nitrogen oxides was studied. Studies of catalysts by XPS showed in the spectra of spent (exhausted) catalyst intense bands characteristic of the sulfur-p-2 electrons, the concentration of which is comparable with the concentration of the active metal. $\mathrm{SO}_{2}$ reaction braking effect is manifested both in the presence of oxygen and in the absence thereof. The maximum activity in the reaction demonstrated previously treated with acid samples of catalysts. Such catalysts are more resistant to the effects of sulfur dioxide. Activity of catalysts samples which were pretreated with acids in the presence of $\mathrm{SO}_{2}$ in the reaction mixture was even slightly higher than in its absence ${ }^{24}$. Processing of a catalyst sample with more dilute acid (0.25-0.5 $\mathrm{N}$ ) increases the concentration of strong acid sites, thereby increasing the activity of these samples during the oxidation.

Emission spectral analysis results of samples treated with sulfuric acid of various concentrations, showed a different degree of dealumination, i.e. reduction of the total concentration of acid sites is associated with significant decrease in the content of $\mathrm{Al}_{2} \mathrm{O}_{3}$ in clinoptillolite treated with sulfuric acid. The maximal activity was shown by $\mathrm{H}$-forms of a natural clinoptillolit at which processing the solutions of sulfuric acid with 0.25-0.5 N were applied (Figure.3)

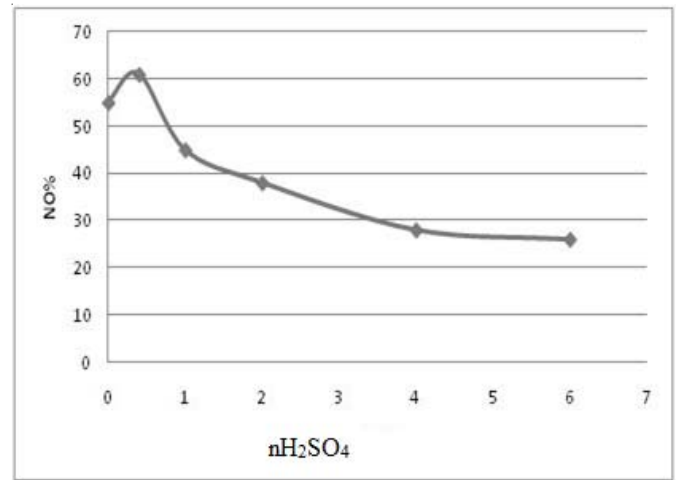

Fig.3: Dependence of conversion of transformation of $\mathrm{NO}$ to $\mathrm{N}_{2}$ at $400^{\circ} \mathrm{C}$ on preliminarily activated $\mathrm{H}$-forms of a natural clinoptillolit from concentration of sulfuric acid

Activity of the $\mathrm{H}$-form of samples of a natural clinoptillolit at which modifying were used solutions of sulfuric acid of various concentration in the direct ratio increased a catalytic activity with a decrease of concentration of sulfuric acid. At modifying of the washcoat on the base of clinoptillolit of $\mathrm{H}$-form with $\mathrm{Fe}$ - and Co-containing components the permanence of activity of these catalysts in the reaction mixtures with $\mathrm{SO}_{2}$ at $\mathrm{NO}$ reduction is observed. 
In this work influence of oxygen on activity and stability of metal block catalysts was studied. It was found that in the presence of $3 \%$ oxygen the catalyst activity with increasing from $200^{\circ}$ to $300^{\circ} \mathrm{C}$ was considerably increased, especially it was noticeable for $\mathrm{Co}+\mathrm{Mn}$ and $\mathrm{Ni}+\mathrm{Mn}$. Increase in content of oxygen to $10 \%$ reduces effectiveness of catalysts. Influence of oxygen was considerably shown in the range of temperatures $250-300^{\circ} \mathrm{C}$
(Table.2). The most resistant against oxygen influence nickel-manganese catalyst promoted with $0.1 \mathrm{wt} \% \mathrm{Pt}$.

Research of Pt and Pd catalysts on thermo stability was carried out by maintaining of the catalyst with an interval of $5 \mathrm{~h}$ at $\mathrm{T}=500^{\circ} \mathrm{C}$ in a reactionary gas mixture with the contents of $0.5 \%$ of propane-butane with the subsequent analysis of products of reaction. The total duration of

Table. 1: Influence of conditions of modifying on activity of the $\mathrm{H}$-form of a natural clinoptillolit in selective catalytic reduction (SCR-process)

\begin{tabular}{lccc}
\hline $\begin{array}{l}\text { Concentration } \\
\text { of sulfuric acid }\end{array}$ & $\begin{array}{c}\text { The degree } \\
\text { of dealumination, } \%\end{array}$ & $\begin{array}{c}\text { The degree of } \\
\text { NO conversion, \% } \\
\text { (dealuminated samples) }\end{array}$ & $\begin{array}{c}\text { The degree of } \\
\text { NO conversion, \% } \\
\text { (activated samples) }\end{array}$ \\
\hline 6.0 & 38.5 & 12.5 & 25.0 \\
2.0 & 31.1 & 30.0 & 43.0 \\
1.0 & 23.2 & 38.0 & 42.0 \\
0.5 & 13.7 & 46.0 & 70.0 \\
0.25 & 5.9 & - & 62.0 \\
\hline
\end{tabular}

Table. 2: The effect of oxygen concentration on the nitrogen oxide conversion by propane-butane mixture

Catalyst The degree of conversion of nitrogen oxide, $\%$ at various oxygen content, $\%$

\begin{tabular}{lcccccccc}
\hline & 3.0 & & 5.0 & & 7.0 & & 10.0 \\
& $250^{\circ} \mathrm{C}$ & $300^{\circ} \mathrm{C}$ & $250^{\circ} \mathrm{C}$ & $300^{\circ} \mathrm{C}$ & $250^{\circ} \mathrm{C}$ & $300^{\circ} \mathrm{C}$ & $250^{\circ} \mathrm{C}$ & $300^{\circ} \mathrm{C}$ \\
\hline $\mathrm{Ni}+\mathrm{Mn}+\mathrm{Pt}$ & 65.0 & 75.0 & 62.0 & 70.0 & 40.0 & 58.0 & 12.0 & 25.0 \\
$\mathrm{Co}+\mathrm{Mn}+\mathrm{Pt}$ & 69.0 & 75.0 & 23.0 & 65.0 & 0 & 35.0 & 0 & 20.0 \\
$\mathrm{Fe}+\mathrm{Mn}+\mathrm{Pt}$ & 71.0 & 80.0 & 0 & 38.0 & 0 & 16.0 & 0 & 0 \\
$\mathrm{Co}+\mathrm{Mn}$ & 23.0 & 72.0 & 0 & 32.0 & 0 & 0 & 0 & 0 \\
$\mathrm{Ni}+\mathrm{Mn}$ & 35.0 & 88.0 & 0 & 38.0 & 0 & 10.0 & 0 & 0 \\
$\mathrm{Fe}+\mathrm{Mn}$ & 52.0 & 60.0 & 0 & 25.0 & 0 & 0 & 0 & 0 \\
\hline
\end{tabular}

researches was 100 hours. It was found that the most stable appeared the catalysts obtained from acetates $\mathrm{Pt}$, less stable - on basis palladium..

High thermal stability of the oxide washcoat is provided with introduction to it of the modifying additives. For example, into the alumina washcoat are introduced cations of cerium, zirconium, lanthanum, which do not only stabilize $\gamma-\mathrm{Al}_{2} \mathrm{O}_{3}$ phase, but also provide resistance to poisons or sintering of $\mathrm{Pt}, \mathrm{Pd}, \mathrm{Rh}$-active components of the catalysts ${ }^{25-27}$. In this work metal block Pd-Mo- catalysts on $\mathrm{Al}_{2} \mathrm{O}_{3}$ carrier modified by additives of $\mathrm{Ce}, \mathrm{Ti}, \mathrm{Zr}$, La and Fe are prepared and researched in reaction of $\mathrm{NO}_{x}+\mathrm{C}_{3} \mathrm{H}_{6}+\mathrm{O}_{2}$. Activity of Pd-Mo of catalysts increases when modifying the washcoat with cations of $\mathrm{Ce}^{4}+, \mathrm{Zr}^{4}+$. Activity of Pt-Cu catalysts on the zeolite-containing washcoats NaY, ZSM-5 and their hydrogen forms was studied.

It was found that adding to the composition of washcoats of titanium dioxide considerably increased extent of reduction of nitrogen oxides by means of propylene on both compositions of oxidic 
catalysts in all interval of the studied temperatures $\left(150-500^{\circ} \mathrm{C}\right)$. Promotion with platinum improved the reduction ability of cobalt-manganese catalyst on alumina only at temperatures higher than $400^{\circ} \mathrm{C}$. On the titanium-containing sample in the presence of platinum degree of $\mathrm{NO}$ conversion decreased.

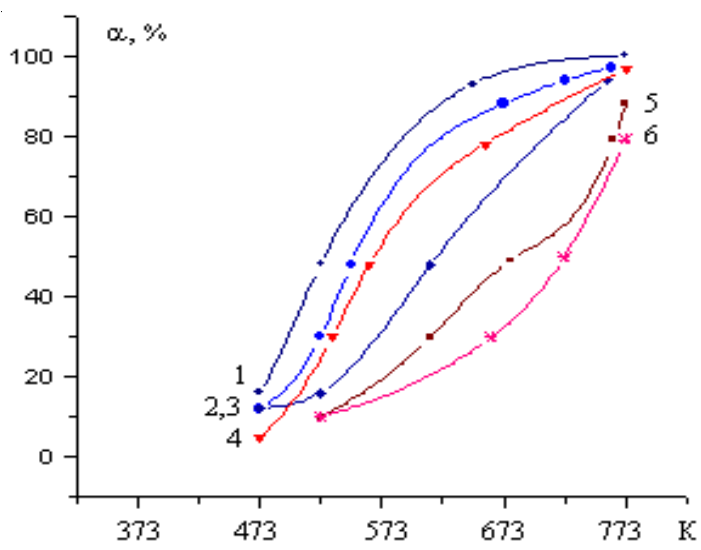

Fig.4. Dependence of stability of catalysts in reaction of $0.5 \%$ of propane-butane in air oxidation: $1-0.1 \% \mathrm{Pt}-$ initial Pt, 2- $0.1 \% \mathrm{Pt}-50 \mathrm{~h}$. of testing, 3-0.1\% Pt100 h., 4- 0.2\% Pd-initial Pd, 5- 0.2\% Pd-50 h. of testing, 6- $0.2 \% \mathrm{Pd}-100 \mathrm{~h}$. of testing

The X-ray phase analysis of $\mathrm{Pd}$ and $\mathrm{Pt}$ showed dispersion of a spectrum that testified the high dispersion of the metals ${ }^{23}$. The metal-organic $\mathrm{Pd}$ and $\mathrm{Pt}$ complexes at magnification of 33,000 times represented translucent areas of the clots of polymer filled with dispersed particles of $\sim 3 \mathrm{~nm}$ in size. At higher magnification (by 62,000 times) the small rare congestions of more dense particles of approx. $5 \mathrm{~nm}$ in size were observed as well. In Fig.5, 6 the nano-dimensional particles of $\mathrm{Pt}$ and $\mathrm{Pd}$ obtained by introduction of the corresponding salts to the PEG water solution and applied on a carrier

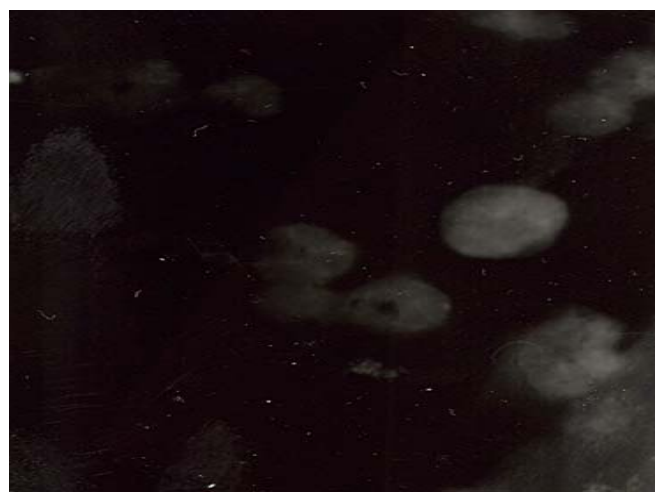

Fig.5. Fragment of Pd cluster surface, are revealed. The images were made at 300,000 -fold magnification. The sizes of $\mathrm{Pt}$ and $\mathrm{Pd}$ particles were approx. 7-8 nm and $11 \mathrm{~nm}$ respectively.

At a diffractogram of catalysts on the basis of a cobalt (Fig.7) there are diffraction peaks which are correspond to oxide of a cobalt of structure of a spinel $\mathrm{Co}_{3} \mathrm{O}_{4}\left(\mathrm{CoCo}_{2} \mathrm{O}_{4}\right): 2 \theta=31.35 ; 36.90 ; 44.90$; 59.40; 55.90

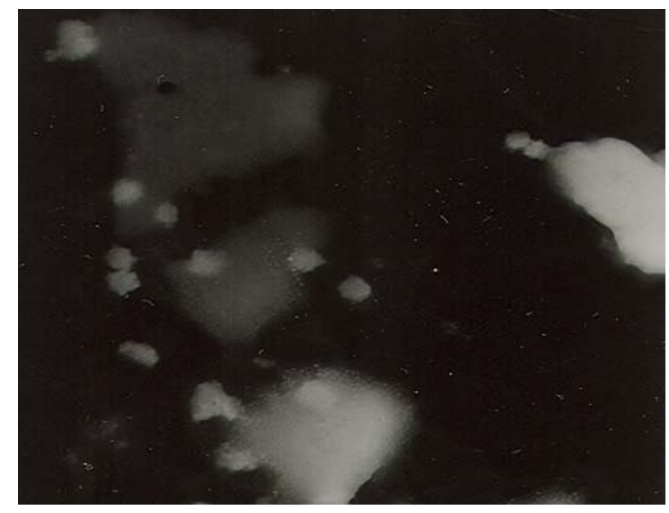

Fig.6. Small congestions of denser particles of Pd

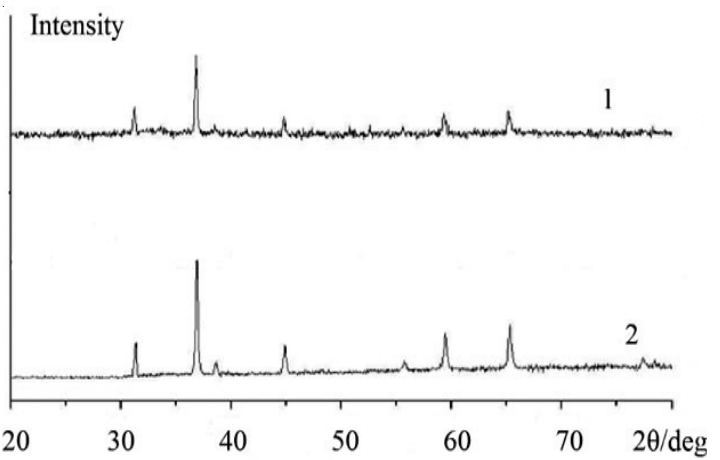

Fig.7. XRD-patterns of different catalysts samples on the base of $\mathrm{Co:} 1-\mathrm{Co} / \mathrm{Al}_{2} \mathrm{O}_{3}, 2-\mathrm{Co}_{3} \mathrm{O}_{4}$

For the catalysts based on $\mathrm{Pd}$ supported on different washcoats the (111) peak of $\mathrm{Pd}(402 \theta)$ and peaks of Pd 46.5 (plane 200), 68.2 (plane 220) were found. Results of XRD showed that there were clear particles of $\mathrm{Pd}^{21}$.

In Table 3, the characteristics of catalysts on base of $\mathrm{Pt}$ and $\mathrm{Pd}$ received with use of method TPD $\mathrm{NH}_{3}$ are presented. The data show that a total (summarized) concentration of acid centers Pt-and $\mathrm{Pd}$-catalysts with the additives of nickel and manganese oxides, above, than in initial Alplatinum and Pd-catalysts. 
In Fig. 8 the comparative diagrams for catalysts with various concentrations of the acid centers of different force were submitted. The catalysts on basis $\mathrm{Pt} / \mathrm{Ni}-\mathrm{Mn} / \mathrm{Al}_{2} \mathrm{O}_{3}$ were characterized by the greatest concentration of the strong acid centers $(280 \mu \mathrm{mol} / \mathrm{g})$, at $\mathrm{Pd} / \mathrm{Ni}-\mathrm{Mn} / \mathrm{Al}_{2} \mathrm{O}_{3}$ catalyst the greatest concentration of the weak acid centers $250 \mu \mathrm{mol} / \mathrm{g}$.

Also it was found, that the oxide catalysts represented spinel with cubic lattice $\mathrm{NiMnO}_{4}$ with

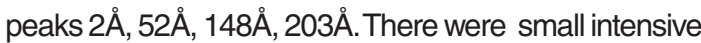
peaks of $\mathrm{CeO}_{2}(308 \AA \AA)$ and alumina $(160 \AA \AA, 256 \AA)^{21}$.

The activity of full-size samples of catalysts was investigated at the stand on the basis of diesel generator. Test data of the full-size block catalyst in the bifunctional mode at various loadings of operation of the engine are presented in Table 4. For the catalyst with $0.1 \%$ Pt effectiveness was already at $267^{\circ} \mathrm{C}$, the degree of conversion of $\mathrm{CO}$ was equal to

Table. 3: The characteristics of the Pt- and Pd-catalysts

\begin{tabular}{lccc}
\hline Catalyst & $\begin{array}{c}\text { Characteristic of the porous structure } \\
\text { Specific surface, } \mathrm{m}^{2} / \mathrm{g}\end{array}$ & $\begin{array}{c}\text { Total concentration } \\
\text { The pores } \\
\text { volume, } \mathrm{cm}^{3} / \mathrm{g}\end{array}$ & $\begin{array}{c}\text { of } \\
\text { of } \mathrm{NH}_{3} \text { adsorption, } \mu \mathrm{mol} / \mathrm{g}\end{array}$ \\
\hline $\mathrm{Pt} / \mathrm{Al}_{2} \mathrm{O}_{3}$ & 200 & 0.348 & 240 \\
$\mathrm{Pd} / \mathrm{Al}_{2} \mathrm{O}_{3}$ & 205 & 0.356 & 110 \\
$\mathrm{Pd} / \mathrm{Ni}-\mathrm{Mn} / \mathrm{Al}_{2} \mathrm{O}_{3}$ & 350 & 0.274 & 620 \\
$\mathrm{Pt} / \mathrm{Ni}-\mathrm{Mn} / \mathrm{Al}_{2} \mathrm{O}_{3}$ & 370 & 0.290 & 660 \\
\hline
\end{tabular}

Table. 4: Results of the analysis of toxic emissions on the diesel generator on the platinumcontaining block catalyst at various loads

\begin{tabular}{lcccc}
\hline Power consumption, kVA & $\begin{array}{c}\text { Temperature of exhaust } \\
\text { gases, }{ }^{\circ} \mathrm{C}\end{array}$ & \multicolumn{2}{c}{$\begin{array}{c}\text { The content of toxic components } \\
\text { in the exhaust gas, \% }\end{array}$} \\
\cline { 3 - 5 } & & CO & $\mathrm{C}_{\mathrm{x}} \mathrm{H}_{\mathrm{y}}$ & $\mathbf{N O}_{\mathbf{x}}$ \\
\hline Idlling (0) & 20 & 90.6 & 21.5 & 3.0 \\
2 & 267 & 99.6 & 80.7 & 44.4 \\
3 & 308 & 100 & 95.6 & 61.1 \\
4 & 427 & 100 & 99.0 & 61.9 \\
\hline
\end{tabular}

$99.6 \%$, hydrocarbons - $80.7 \%$, nitrogen oxide was $44.4 \%$. With an increase in engine power of up to $3-4$ kVA is observed high activity on $\mathrm{NO}_{x}(61.1-61.9 \%)$.

Thermal stability of full-size samples of catalysts was determined by definition of activity of the initial catalyst on the diesel generator working under loading $3 \mathrm{kVA}$ with the following fractional calcination of converters at $600^{\circ} \mathrm{C}$ with an interval of $5 \mathrm{~h}$ in a muffle furnace. During 100-h test high heat stability of catalysts was revealed.

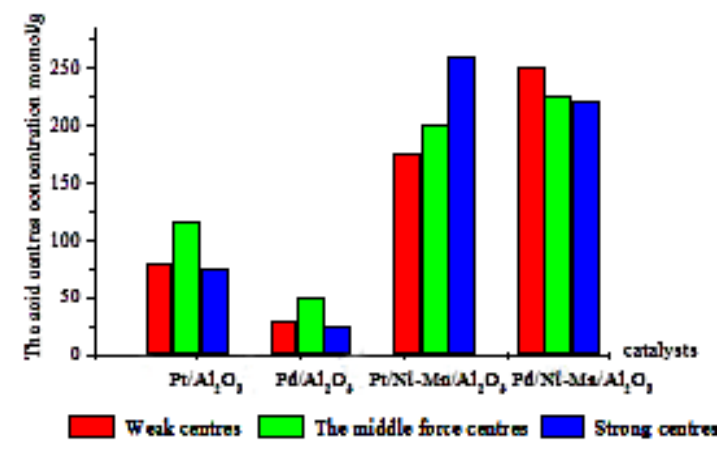

Fig.8. Influence of the chemical composition of the neutralizers on distribution of the acid centres with different forces 


\section{CONCLUSION}

Catalysts for neutralization of toxic gases of the industry and motor transport on metal carriers with the honey comb structure of channels were prepared. As the washcoat was used alumina with the additives of zeolite or compounds of $\mathrm{Ce}, \mathrm{Ti}, \mathrm{Zr}$, $\mathrm{La}$ and Fe. For preparation of solutions of the active components of catalysts are also applied oxides of $\mathrm{Mn}, \mathrm{Ni}, \mathrm{Co}, \mathrm{Fe}$ (obtained from acetates and formates) and the samples of catalysts on the base of the platinum group metals. Stability of the carrier and the active phase of catalysts to poisons $\mathrm{SO}_{2}$ and oxygen in processes of cleaning of exhaust gases was studied. The braking effect of reduction reaction of nitrogen oxide is shown by adding $\mathrm{SO}_{2}$ both in the presence of oxygen and in the absence thereof. Adding into a composition of the washcoat of a clinoptilolit of the Shankanaysky field increased resistance of catalysts to poisoning with catalytic poisons. The catalysts stability against poisoning with compounds of sulfur are developed. Influence of oxygen was considerably shown in the range of temperatures $250-300^{\circ} \mathrm{C}$. The Ni-Mn catalyst with additive of $0.1 \%$ (wt.) Pt was the steadiest against oxygen influence. At tests of full-size samples at the stand on the basis of the diesel generator degree of conversion of CO was $99.6 \%$, hydrocarbons- $80.7 \%$, nitrogen oxides $-60-61.9 \%$.

\section{ACKNOWLEDGEMENTS}

We would like to express sincere gratitude to the Ministry of Science and Education of the Republic of Kazakhstanfor grant financing (Project 2014-2017)

\section{REFERENCES}

1. O'Neill, B.C. J.Science. 2002, 5575, 1971

2. Sendilvelan, S.; Bhaskar, K.; Nallusamy S. Rasayan J. Chem. 2017, 10(2), 454 - 460

3. Alexandrov, Yu.A.; Ivanovskaya, K.E.; Vorozheykin, I.A. J. of Appl.Chem.2003, 8, 1298

4. Rauch, S.; Harold, H.F.; Barbante, C.; Masanori, O.; Morrison, G.M.; Peucker-Ehrenbrink, B.; Wass, U. J. Environ. Sci.Technol. 2005, 1, 8156

5. Takami, A.; Ichikawa, T. J. Zeolites. 1995, 15(3), 283

6. Sendilvelan, S.; Bhaskar K. Rasayan J. Chem. 2017, 10(3), 1043-1049

7. Val'dberg, A.Yu; Kosogorova, T.O.; Tsedilin, A.N.; Pokrovskii, D.D.; Yakimychev, A.A.; J.Chemical and Petroleum Engineering. 2007, 5-6, 287-291

8. Awofeso, N. American Journal of Respiratory and Critical Care Medicine. 2011, 10, 1437

9. Prabhahar, M.; Murali Manohar, R.; Sendilvelan, S.; European Journal of Scientific Research, 2012, 73(4), 504-511

10. McGrath, M. Four major cities move to ban diesel vehicles by 2025. http://www.bbc.com/ news/science-environment-38170794

11. Yang, S.; He, L-Y. J.Energy \& Environment. 2016.

12. Sendilvelan, S.; Bhaskar, K. Rasayan., J.Chem. 2017, 10(1), 111-116.

13. Sendilvelan, S.; Bhaskar, K. Orient J Chem. 2017, 33(4), 2111

14. Karol, I.L.; Kisselev, A.A. Priroda. 2003, 6, 18

15. Inozemtsev, V.L. Priroda, 2001, 1, 20

16. Murali Manohar, R.; Prabhahar, M.; Sendilvelan, S. European Journal of
Scientific Research. 2012, 76(3), 327-334

17. Sendilvelan, S.; Rajan, K. Rasayan Journal of Chemistry, 2017, 10 (1), 190

18. Lee, B.Y.; Inoue, Y.; Yasimori, I. J Bull Chem Soc Jpn. 1981, 54, 3711

19. In, B.D.; Kim, H.; Son, J.; Lee, K. Intern. J. Heat and Mass Transf. 2015, 86, 667 - 680

20. Sendilvelan, S.; Bhaskar, K. Rasayan J.Chem. 2016, 9(4), 692-696

21. Sassykova, L.; Gil'mundinov, Sh.; Nalibayeva, A.; Bogdanova, I. Revue Roumaine de Chimie, 2017, 2, 107-114

22. Sassykova, L.R.; Nalibayeva, A.; Gil'mundinov, Sh.A. Bulgarian Chemical Comm. 2017, 49(3), 583-588.

23. Sassykova, L.; Nalibayeva, A; Aubakirov, Y.; Tashmukhambetova, Zh.; Otzhan, U; Zhakirova, N.; Faizullaeva, M., Orient J Chem. 2017, 33(4), 1941-1948

24. Sassykova, L.R.; Massenova, A.T.; Gilmundinov, Sh.A.; Bunin, V.N.; Rakhmetova, K.S.; DGMK, Tagungsbericht., 2014, 3, 181-188

25. Shuy, J.S.; Weber, W.H.; Gandhi, H.S. J.Phys.Chem. 1988, 17, 4964

26. Burdeinaya, T.N.; Matyshak, V.A.; Tret'yakov, V.F.; Glebov, L.S.; Zakirova, A.G.; Carvajal, G., Villanueva, A.M.E. J.Appl.Catalysis B:Environmental. 2007, 1-4, 128.

27. Kramer, M.; Schmidt, T.; Stowe, K.; Maier, W.F. Applied Catalysis A: General, 2006, 302, 257-263. 